\title{
Observation of Financial Literacy among the Selected Students in the U.S. and Japan
}

\author{
Kenichiro Chinen ${ }^{1} \&$ Hideki Endo ${ }^{2}$ \\ ${ }^{1}$ College of Business Administration, California State University, Sacramento, California, USA \\ ${ }^{2}$ Faculty of Economics, Nihon Fukushi University, Aichi, Japan \\ Correspondence: Ken Chinen, College of Business Aministration, California State University, Sacramento, \\ Sacramento, CA 95819, USA. Tel: 1-916-278-6882. E-mail: chinenk@csus.edu
}

Received: June 4, 2014

doi:10.5539/ijef.v6n9p95
Accepted: June 13, 2014

Online Published: August 25, 2014

\begin{abstract}
This study examined the level of financial literacy and confidence in making own financial decisions college students in US and Japan. A total of 575 undergraduate students, 359 undergraduate students in Sacramento, the state capitol of California, and 216 undergraduate students in Aichi prefecture, located near the center of the Japanese main island, participated in this study. Financial literacy was measured by two instruments: Survey of Personal Financial Literacy Among College Students in Jump\$tart and the three questions developed by Lusardi and Mitchell. The US collegiate students selected for this study demonstrated a better understanding of financial literacy compared to Japanese counterparts in both measurement instruments. Nearly a half of Japanese students in this study did not feel that they were ready to make their own financial decisions. Their lack of confidence in making financial decision was regrettably reflected on their poor performance in the financial literacy test. These findings highlight the need for a wholistic approach to financial education in Japan.
\end{abstract}

Keywords: financial literacy, financial education, confidence, comparison, independent samples t-test, U.S., Japan

\section{Introduction}

Financial literacy is "exercising in real life situations the ability to make informed judgments and to take effective decisions regarding the use and management of money" (Balatti, 2007, p. 7). Those who have financial capabilities to make right choices about money and to live within their means are less likely to face financial troubles, such as maxing out their credit cards, not making payments on time, or being compulsive buyers, and are more likely to display healthy financial behaviors, including saving for the future, paying off credit cards in full each month, or being able to prioritize spending according to needs, rather than wants.

Financial literacy becomes especially urgent in times of economic and financial turmoil and uncertainty as evidenced in research and publication trends ( $\mathrm{Ji}$ et al., 2010). Although it is argued that it is difficulty to develop the effective financial education, perhaps mainly due to time and financial constraints (Willis, 2011), researchers, educators, and policy makers would often agree that lack of financial knowledge and skills have contributed to the latest economic and financial crisis (Klapper et al., 2012). Many people, young in particular, have limited understanding of important personal finance topics as budgeting, investment, credit, and spending which leads to making wrong financial decisions and aggravating the crises. It is reported that youths with lower financial literacy would face a higher risk of health problems including a higher incidence of persistent sleeplessness and a higher desire to smoke (Marcolin \& Abraham, 2006). As warned by Charles Schwab (2008, VII) in his letter to President Bush, "Far too many Americans entered into home and other loan agreements that they did not understand and ultimately could not afford. More broadly, the lack of basic skills such as how to create and maintain a budget, understand credit, or save for the future, are preventing millions of Americans from taking advantage of our vibrant economic system."

Experts agree that there is urgent need of financial literacy and education for people around the world of all education levels, from China to Japan to Germany to the United States, especially those who struggle to make sound decisions about even the simplest financial matters (Lusardi \& Mitchell, 2011). These issues are wide spread all over the world and we find it interesting to conduct comparative research on the status of financial 
literacy.

The authors of this study collected baseline information on financial literacy among college students in Japan using existing financial literacy test instruments and methods and, then, compared those results with that from the US. Use of identical questions to measure the level of financial literacy enabled us to compare the level of financial literacy in the US and that in Japan. These countries were chosen because the US and Japan, if combined, account for roughly 30 percent of world domestic product. They also account for a significant portion of international trade in goods and services, and for a major portion of international investment. Therefore, we cannot afford to ignore financial well-being of young consumers in these countries. The first section in this study reviews research on financial literacy around the world. Then we present research questions regarding the US and Japan. The second section explains the empirical methodology and data employed in the analysis. The third section presents the results. The study ends with some concluding remarks and implications.

\section{Literature Review}

\subsection{Financial Literacy Research around the World}

The need for personal finance education has been identified in many countries and is well-documented by current research in the field. For instance, Bucher-Koenen and Lusardi (2011) examined financial literacy in Germany and found that knowledge of basic financial concepts was lacking among women, the less educated, and those living in East Germany, particularly those with low education and low income in East Germany.

Worthington (2006) investigated factors affecting financial literacy in Australia, including gender, age, ethnicity, occupation, education, income, savings, and debt. It was found that persons aged between 50 and 60 years, professionals, business and farm owners, and college graduates had highest financial literacy. Literacy was lowest for the unemployed, females, and those from a non-English speaking background with a low level of education.

Based on a sample of 400 young male Australian workers, Dowling et al. (2009) found that financial management practices (e.g., I set money aside for retirement) and money attitudes (e.g., Things I own say a lot about how well I'm doing in life) significantly predicted financial problems (e.g., I cannot afford to buy adequate insurance; I don't have enough money for doctor, dentist, or medicine).

An empirical analysis conducted by Fornero and Monticone (2011) showed that most individuals in their study lacked knowledge of basic concepts of financial literacy, such as interest rates and inflation, in Italy. They found that educated men living in the Centre-North possessed higher financial literacy. They also found that financial literacy had a positive and significant impact on the probability of pension plan participation.

Hussain et al. (2008) investigated the financial needs of business owners or managers in UK and found that owner or managers of micro-businesses had lower educational achievements as well as higher financial education needs than their counterparts in small and medium-sized firms. Owner or managers in small and medium sized business had relatively higher educational achievements and a better appreciation of the role of financial education.

After the Asian crisis, Lown and Ju (2000) suggested how Korean consumer and family economics educators and counselors could assist families in coping with the economic disorder resulting from the Asian crisis. They reviewed the macroeconomic conditions and financial education in South Korea around the year of crisis, 1998, then proposed offering of various training and certificate programs and adaption of western-style programs of financial education and counseling in a culturally acceptable manner through international collaborations, such cross cultural and education exchanges.

Ali et al. (2013) examined the factors that contributed to the level of financial literacy among Malaysian citizens and its relationship with financial satisfaction. They identified five antecedents of the financial literacy index: basic money management, financial planning, investment know-how, attitude to money and financial activities. Financial planning was found to exhibit the strongest effect on the financial literacy level.

Klapper and Panos (2011) examined the relationship between financial literacy and retirement planning in Russia and found that only 36 percent of respondents in their study understood interest compounding and only half could answer a question about inflation. They found that financial literacy was significantly and positively related to retirement planning involving private pension funds. They found that residents in rural area were much more reliant on the public provision, investing less in private schemes and savings.

Shahrabani (2012) analyzed the factors affecting intent to control a personal budget among Israeli college students and found that intention to budget among students was influenced by past debt frequency, level of 
negative emotions experienced by participants when their bank account was significantly overdrawn, financial literacy level, income, and nationality. They also found positive attitudes toward financial management moderate the negative impact of past debt frequency on the intention to control a personal budget without significant debt.

\subsection{Financial Education and Literacy: US and Japan}

There has been a surging interest in financial literacy by US financial institutions and their associations. Since 2001 Federal Deposit Insurance Corporation (FDIC) offers financial education program called Money Smart which offers a wide range of financial education curriculum targeting low-to-moderate income individuals to enhance their financial skills. In 2009, more than 20 federal agencies had initiatives related to improving financial literacy. In some cases, federal agencies are directly involved in financial education program (US Government Accountability Office, 2011). For example, Federal Reserve Board-founded Jump\$tart Coalition for Personal Financial Literacy surveys the financial literacy of high school students and the response. Likewise, the Community Financial Access Pilot, a program under the U.S. Department of the Treasury, "began in 2008 and was implemented through December 2009 by the US Department of the Treasury to increase access to financial services and financial education among low- and moderate-income families and individuals, especially individuals who have no bank or credit union account" (U.S. Department of Treasury, 2012).

Research by the OECD (2006) and Lusardi and Mitchell (2007) found that financial illiteracy was common in many developed countries such as Australia, Japan, and Korea, as well as developed countries in Europe. Using data on over 4,700 Japanese households, Sekita (2011) examined financial literacy in Japan and concluded that the level of financial literacy was not high in Japan. The study found that women, the young, and those with lower incomes and lower education attainment had the lowest levels of financial literacy, and financial literacy increased the probability of having a retirement savings plan. Sekita used three questions measuring understanding of compound interest, inflation, and risk diversification (Lusardi \& Mitchell, 2006) in her study and concluded that the level of financial literacy in Japan was low. Sekita (2011) expressed her concerns that 13, 29, and 56 percent of Japanese respondents could not answer correctly to simple questions of interest rate, inflation, and risk diversification, respectively. The proportions of respondents who answered incorrectly to the same questions were 2, 4, and 25 percent in the US and 4, 9, and 27 percent in Netherland (Van Rooij et al., 2007). These findings lead to the following research question:

What is the level of financial literacy in Japan compared to that in US amongst college students?

Robb et al. (2012) studied the role of financial knowledge, satisfaction, and confidence and found that consumers with more knowledgeable and confident in one's own money management skills would be more likely to use an advice from other knowledgeable people to avoid costs associated with poor financial decisions. Stated differently, those with less knowledgeable and confident in their money management skills would be less open to suggestions by others. Sekita (2011) highlights findings in reports by the Hartford Financial Services conducted in 2008 regarding international retirement survey in nine countries. According to the report, the proportion of individuals who were not confident about having enough money for retirement was the highest in Japan among the nine countries at 35 percent. The rates in other countries were 6 percent in Spain, 10 percent in Italy, South Korea, US, Taiwan, and Germany. The proportion of individuals who were not confident in knowledge and ability with financial planning at all was extremely high in Japan at 28 percent, compared to 7 to 11 percent in other countries. This leads to the following research question:

\section{What is the level of financial confidence in Japan compared to that in US amongst college students?}

\section{Method}

Undergraduate students were the focus of this study because for many, the foundation of financial autonomy would be laid down during the college years. A total of 575 undergraduate students, 359 undergraduate students in Sacramento, the state capitol of California, and 216 undergraduate students in Aichi prefecture, located near the center of the Japanese main island, participated in this study between fall of 2011 and fall of 2012. Appendix 1 presents the demographic profile of the respondents.

Financial literacy in this research was measured by two instruments: Survey of Personal Financial Literacy Among College Students in Jump\$tart (Mandell, 2008) and the three questions developed by Lusardi and Mitchell (2006). Although it is hard to capture all of this information in a survey of reasonable length, financial literacy measured in Lusardi and Mitchell (L-M) and Jump\$tart encompass a number of concepts, including financial awareness and knowledge, financial skills and financial capability. To insure that there were not substantial cultural barriers inherent in answering questions, we used questionnaires already translated into 
standard Japanese language: the L-M survey by Global COE Program in Osaka University (Note 1), and Jump\$tart survey in research by Kusumoto (2006). Appendix 2 presents the survey used for this research.

\section{Results}

\subsection{Financial Literacy}

An independent samples t-test was applied to investigate the mean difference between students who answered correctly on financial literacy questions in the US and that in Japan. First, we report results of three questions developed by Lusardi and Mitchell (2006). The precise wording of the three basic financial literacy questions used in this study is as follows:

\section{Inflation}

Imagine that the interest rate on your savings account was 1 percent per year and inflation was 2 percent per year. After one year, you would be able to buy today with the money in this account.

A. more than; B. exactly the same as; C. less than (correct answer).

\section{Compound Interest Rate}

Suppose you had $\$ 100$ in a savings account and the interest rate was $2 \%$ per year. After 5 years, how much do you think you would have in the account if you left the money to grow?

A More than $\$ 102$ (correct answer); B. Exactly \$102; C. Less than $\$ 102$.

\section{Risk Diversification}

Do you think that the following statement is true or false? "Buying a single company stock usually provides a safer return than a stock mutual fund.

A. True; B. False (correct answer).

Responses for each question were re-coded into a dichotomous variable, where value of 0 was assigned for incorrect response and 1 for correct response. This study found significant differences between the US and Japanese students (Table 1): the proportion of US students correctly answered the Inflation question was 74.4 percent $(\mathrm{SD}=.437)$ compared to 47.4 percent of Japanese students $(\mathrm{SD}=.500)$, with $\mathrm{t}$-value $=6.750$ where p-value was statistically significant $(<.01)$; the proportion of the US students who correctly answered the Compound interest rate question was 87.2 percent $(\mathrm{SD}=.335)$ compared to 65.2 percent of Japanese students $(\mathrm{SD}=.477)$, with $\mathrm{t}$-value $=6.453$ where $\mathrm{p}$-value was statistically significant $(<.01)$; the proportion of the US students who answered correctly for the Risk diversification question was 87.5 percent $(\mathrm{SD}=.332)$ compared to 57.8 percent of Japanese students $(\mathrm{SD}=.495)$, with $\mathrm{t}$-value $=8.547$ where p-value was statistically significant $(<.01)$. Although both the US and Japanese students were expected to show higher performance on these three basic questions, the US students achieved better results in contrast with the Japanese counterparts. It was reported that the concept of geometric progression has been required to be taught in middle school since 1951 (Sekita, 2011). Thus, Japanese college students should be able to answer these questions correctly.

Table 1. Results of independent samples t-test on financial literacy score (L-M): US vs Japan

\begin{tabular}{|c|c|c|c|c|c|c|}
\hline Group variables & & $\mathrm{N}$ & Answered correctly & Mean & SD & t-value \\
\hline \multirow{2}{*}{ Inflation } & US & 359 & 267 & .744 & .437 & $6.750 * *$ \\
\hline & Japan & 213 & 101 & .474 & .500 & \\
\hline \multirow[t]{2}{*}{ Compound interest rate } & US & 359 & 313 & .872 & .335 & $6.453 * *$ \\
\hline & Japan & 216 & 141 & .652 & .477 & \\
\hline \multirow[t]{2}{*}{ Risk diversification } & US & 359 & 314 & .875 & .332 & $8.547 * *$ \\
\hline & Japan & 211 & 122 & .578 & .495 & \\
\hline
\end{tabular}

Note. $*, * *$ indicate that the difference is significant at 5-percent and 1-percent levels, respectively.

Next, differences of means for the seven Jump\$tart questions between the US and Japan were analyzed (Tables $2 \mathrm{~A}$ to $2 \mathrm{G}$ ) through the independent samples t-test. Responses for each of seven questions were re-coded into a dichotomous variable, where value of 0 was assigned for incorrect response and 1 for correct response. For the six of seven questions, the US collegiate students participated in this study demonstrated a significantly better achievement in answering questions correctly in Jump\$tart compared to the Japanese students. Regarding the safest place to save money, the difference between the US and Japan was statistically significant (US: mean 
$=.928, \mathrm{SD}=.260 ;$ Japan: mean $=.795, \mathrm{SD}=.404 ; \mathrm{t}$-value $=4.770$ where $\mathrm{p}$-value was statistically significant at .01 level). Though 81 percent of Japanese students correctly answered the question, 11.4 percent, or roughly one of ten Japanese students believed that locked in the closet at home was the safest place to save money.

Table 2A. Comparison of financial literacy (Jump\$tart): safest place to save money

Rebecca has saved $\$ 12,000$ for her college expenses by working part-time. Her plan is to start college next year and she needs all of the money she saved. Which of the following is the safest place for her college money?

\begin{tabular}{|c|c|c|c|c|c|}
\hline \multirow[b]{2}{*}{ Alternatives } & \multicolumn{2}{|c|}{ US } & \multicolumn{2}{|c|}{ Japan } & \multirow[t]{2}{*}{ t-value } \\
\hline & $\mathrm{N}($ Mean) & $\%(\mathrm{SD})$ & $\mathrm{N}($ Mean) & $\%(\mathrm{SD})$ & \\
\hline 1. Locked in her closet at home & 5 & 1.4 & 24 & 11.4 & \\
\hline 2. Stocks & 4 & 1.1 & 5 & 2.4 & \\
\hline 3. Corporate bonds & 17 & 4.7 & 11 & 5.2 & \\
\hline 4. A bank savings account (correct answer) & 333 & 92.5 & 171 & 81.0 & \\
\hline Answer in alternatives coded as 0 if wrong, 1 if correct. $^{\text {a }}$ & $(.928)$ & $(.260)$ & $(.795)$ & $(.404)$ & $4.770 * *$ \\
\hline
\end{tabular}

Note. ${ }^{*}, * *$ indicate that the difference is significant at 5 -percent and 1-percent levels, respectively.

a If a student picked "A bank savings account," the response was re-coded as one. For any other choices, it was re-coded as zero.

We observed a significant difference between the US and Japan in terms of how they answered the Protecting Family Savings question (Table 2B; US: mean $=.403, \mathrm{SD}=.491 ;$ Japan: mean $=.150, \mathrm{SD}=.357 ; \mathrm{t}=6.567$ where p-value was statistically significant at .01 level). It was interesting to note that over 50 percent of Japanese college students believed a certificate of deposit would protect the purchasing power of a family's savings better than a house financed with a fixed-rate mortgage. Forty percent of the US students answered this question correctly.

Table 2B. Comparison of financial literacy (Jump\$tart): protecting family savings

\begin{tabular}{|c|c|c|c|c|c|}
\hline \multicolumn{6}{|c|}{$\begin{array}{l}\text { Which of the following types of investment would best protect the purchasing power of a family's savings in the event of a sudden } \\
\text { increase in inflation? }\end{array}$} \\
\hline \multirow[b]{2}{*}{ Alternatives } & \multicolumn{2}{|c|}{ US } & \multicolumn{2}{|c|}{ Japan } & \multirow[t]{2}{*}{ t-value } \\
\hline & $\mathrm{N}($ Mean) & $\%(\mathrm{SD})$ & $\mathrm{N}$ (Mean) & $\%(\mathrm{SD})$ & \\
\hline 1. A 10-year bond issued by a corporation & 57 & 15.8 & 41 & 19.5 & \\
\hline 2. A certificate of deposit at a bank & 109 & 30.3 & 114 & 54.3 & \\
\hline 3. A twenty-five year corporate bond & 46 & 12.8 & 23 & 11.0 & \\
\hline 4. A house financed with a fixed-rate mortgage (correct answer) & 143 & 39.7 & 32 & 15.2 & \\
\hline Answer in alternatives coded as 0 if wrong, 1 if correct. & $(.403)$ & $(.491)$ & $(.150)$ & $(.357)$ & $6.567 * *$ \\
\hline
\end{tabular}

Note. ${ }^{*}, * *$ indicate that the difference is significant at 5 -percent and 1-percent levels, respectively.

The independent samples t-test shows that there was a statistically significant difference between the US (mean $=.724, \mathrm{SD}=.448)$ and Japan (mean $=.184, \mathrm{SD}=.388)$ in their response to the Money Management question, with $t=14.783$ where $p$-value was statistically significant at .01 level (See Table 2C). Approximately a half of Japanese respondents answered that invested stock was the least beneficial when they need money right away when the correct response was down payment on house. However, their responses might represent many Japanese people. The former Japanese Prime Minister Taro Aso (AFP, 2009), in the wake of Lehman Brothers Shock, spoke concerns of many Japanese people towards the stock traders:

Japan's Prime Minister Taro Aso made another gaffe on Saturday after saying share traders were regarded as untrustworthy by some Japanese, local media reported, "If you are dealing stocks, you can be somehow regarded as shady in rural areas." 
Table 2C. Comparison of financial literacy (Jump\$tart): money management

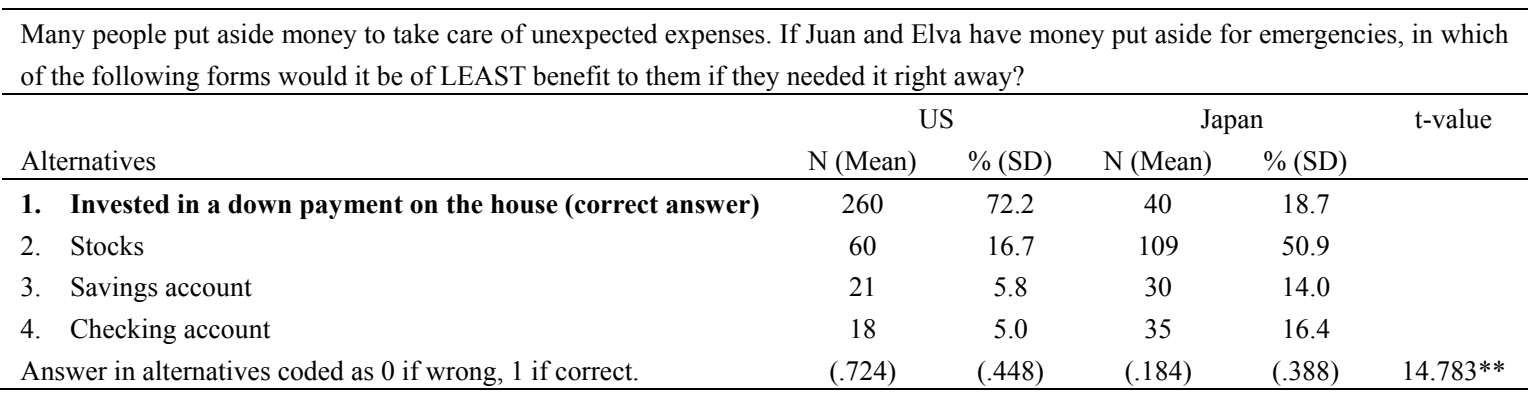

Note. ${ }^{*}, * *$ indicate that the difference is significant at 5 -percent and 1-percent levels, respectively.

Collegiate students should be able to answer basic math-based financial questions in Table 2D and 2E. For the Family Budget question (Table 2D), the US students outscored Japanese counterparts. Approximately 77 percent of the US students answered correctly, compared to 65 percent by Japanese students. There was statistically significant difference between the US and Japan (US: mean $=.773, \mathrm{SD}=.419$; Japan: mean $=.647, \mathrm{SD}=.479$; t-value 3.318 where p-value statistically significantly at .05 level). For the Savings and Retirement question, the gap between the US and Japan was statistically significant $(\mathrm{t}=2.283$ where $\mathrm{p}$-value was statistically significant at .05 level). However, the gap between those who answered the question correctly was roughly 10 points less than six other questions. Approximately 60 percent of the US students answered correctly, compared to 50 percent by Japanese students (Table 2E).

Table 2D. Comparison of financial literacy (Jump\$tart): family budget

\begin{tabular}{|c|c|c|c|c|c|}
\hline \multicolumn{6}{|c|}{$\begin{array}{l}\text { David just found a job with a take-home pay of } \$ 2000 \text { per month. He must pay } \$ 900 \\
\text { month. He also spends } \$ 250 \text { per month on transportation. If he budgets } \$ 100 \text { each mor } \\
\text { and } \$ 250 \text { for everything else, how long will it take him to accumulate savings of } \$ 600 ?\end{array}$} \\
\hline \multirow[b]{2}{*}{ Alternatives } & \multicolumn{2}{|c|}{ US } & \multicolumn{2}{|c|}{ Japan } & \multirow[t]{2}{*}{ t-value } \\
\hline & $\mathrm{N}($ Mean $)$ & $\%(\mathrm{SD})$ & $\mathrm{N}($ Mean $)$ & $\%(\mathrm{SD})$ & \\
\hline 1. One month & 3 & .8 & 6 & 2.8 & \\
\hline 2. Two months & 28 & 7.8 & 28 & 13.0 & \\
\hline 3. Three months & 50 & 13.9 & 40 & 18.6 & \\
\hline 4. Four months (correct answer) & 276 & 76.7 & 141 & 65.6 & \\
\hline Answer in alternatives coded as 0 if wrong, 1 if correct. & $(.773)$ & $(.419)$ & $(.647)$ & $(.479)$ & $3.318^{*}$ \\
\hline
\end{tabular}

Note. ${ }^{*}, * *$ indicate that the difference is significant at 5-percent and 1-percent levels, respectively.

Table 2E. Comparison of financial literacy (Jump\$tart): savings for retirement

Rob and Mary are the same age. At age 25, Mary began saving \$2000 a year while Rob saved nothing. At age 50, Rob realized that he needed money for retirement and started saving $\$ 4000$ per year while Mary kept saving her $\$ 2000$. Now they are both 75 years old. Who has the most money in his or her retirement account?

\begin{tabular}{|c|c|c|c|c|c|}
\hline \multirow[b]{2}{*}{ Alternatives } & \multicolumn{2}{|c|}{ US } & \multicolumn{2}{|c|}{ Japan } & \multirow[t]{2}{*}{ t-value } \\
\hline & $\mathrm{N}($ Mean $)$ & $\%(\mathrm{SD})$ & $\mathrm{N}$ (Mean) & $\%(\mathrm{SD})$ & \\
\hline $\begin{array}{l}\text { 1. They would each have the same amount because they put } \\
\text { away exactly the same }\end{array}$ & 108 & 30.0 & 41 & 19.2 & \\
\hline 2. Rob, because he saved more each year & 13 & 3.6 & 31 & 14.6 & \\
\hline 3. Mary, because she has put away each year & 24 & 6.7 & 33 & 15.5 & \\
\hline $\begin{array}{l}\text { 4. Mary, because her money has grown for a longer time at } \\
\text { compound interest (correct answer) }\end{array}$ & 213 & 59.2 & 108 & 50.7 & \\
\hline Answer in alternatives coded as 0 if wrong, 1 if correct. & $(.595)$ & $(.492)$ & $(.498)$ & $(.501)$ & $2.283^{*}$ \\
\hline
\end{tabular}

Note. ${ }^{*}, * *$ indicate that the difference is significant at 5 -percent and 1-percent levels, respectively.

It needs to be noted that a half of Japanese students chose Checking account to grow education funds (See Table 2F). Since the concept of the checking account and its direct translation in Japanese does not necessarily match, 
we felt that we would need to explain the nature of the checking account in the survey for our future research. Nevertheless, only 13.5 percent of Japanese students chose Stocks to grow education funds as compared to 37 percent by the US counterparts, again reflecting Japanese resistance against the stock market. The independent samples t-test shows that there was a statistically significant difference between the US (mean $=.370, \mathrm{SD}=.483$ ) and Japan $($ mean $=.132, \mathrm{SD}=.339)$ in their response to the question about Savings for Children, with $\mathrm{t}=6.295$ where p-value was statistically significant at .01 level.

Table 2F. Comparison of financial literacy (Jump\$tart): savings for children

\begin{tabular}{|c|c|c|c|c|c|}
\hline \multicolumn{6}{|c|}{$\begin{array}{l}\text { Sara and Joshua had a baby. They received money as baby gifts and want to put it away for the baby's education. Which tends to } \\
\text { have the highest growth over periods of time as long as } 18 \text { years? }\end{array}$} \\
\hline \multirow[b]{2}{*}{ Alternatives } & \multicolumn{2}{|c|}{ US } & \multicolumn{2}{|c|}{ Japan } & \multirow[t]{2}{*}{ t-value } \\
\hline & $\mathrm{N}($ Mean) & $\%(\mathrm{SD})$ & $\mathrm{N}$ (Mean) & $\%(\mathrm{SD})$ & \\
\hline 1. Stocks (correct answer) & 132 & 36.7 & 28 & 13.5 & \\
\hline 2. A government savings bond & 167 & 46.4 & 36 & 17.3 & \\
\hline $\begin{array}{l}\text { 3. A savings account (equivalent to 'Futsuu yokin' or 'checking } \\
\text { account' in Japan) }\end{array}$ & 52 & 14.4 & 35 & 16.8 & \\
\hline $\begin{array}{l}\text { 4. Checking account (equivalent to 'Teiki yokin' or 'Savings } \\
\text { account' in Japan) }\end{array}$ & 6 & 1.7 & 109 & 52.4 & \\
\hline Answer in alternatives coded as 0 if wrong, 1 if correct. & $(.370)$ & $(.483)$ & $(.132)$ & $(.339)$ & $6.295^{* *}$ \\
\hline
\end{tabular}

Our first research question explores whether the level of financial literacy in Japan was low compared to that in the US amongst college students. As presented in Table 1 and Tables $2 \mathrm{~A}$ to $2 \mathrm{~F}$, we observed relatively low levels of financial literacy in Japan compared to that in US amongst selected college students.

All of our findings are based on unrestricted samples. Under this condition, some of the findings may include a sample-selection bias caused by the difference of requirements (e.g., scholastic ability in high school) for enrollment by each college. Past research found that the education level of a parent affects a child's academic achievement (Marjoribanks, 2005; DeDonno \& Fagan, 2013). Melhuish et al. (2013) showed that child's progress in mathematics was associated with his/her parents' educational qualifications. In order to reduce the sample-selection bias, we selected respondents in our sample whose parents have bachelor's degree or higher. Some of t-tests with unequal variances on the comparison of financial literacy score between the US and Japan showed different results from that reported in Table 2. The difference in overall score is remained. However, there were no statistically significant differences in correction rates to three questionnaires between two countries.

\subsection{Confidence}

While 82.8 percent of the US students believed they were well prepared to make their own financial decisions, only 61.5 percent of Japanese students felt confidence in making their own financial decisions (See Table 3A). We observed a significant difference between the US and Japan in terms of their confidence to make own financial decisions, with t-value 5.793 where p-value was statistically significant at .01 level.

Table 3A. Results of independent samples t-test on confidence in making financial decisions: US vs Japan

\begin{tabular}{|c|c|c|c|c|c|c|c|c|}
\hline \multirow[t]{2}{*}{ Group variable } & & \multicolumn{2}{|c|}{$\begin{array}{l}\text { Strongly disagree } \\
\text { or Disagree }\end{array}$} & \multicolumn{2}{|c|}{$\begin{array}{l}\text { Agree or Strongly } \\
\text { agree }\end{array}$} & \multirow[b]{2}{*}{ Mean } & \multirow[b]{2}{*}{ SD } & \multirow[b]{2}{*}{ t-value } \\
\hline & & $\mathrm{N}$ & $\%$ & $\mathrm{~N}$ & $\%$ & & & \\
\hline I am well-prepared to make & US & 62 & 17.2 & 298 & 82.8 & 1.828 & .378 & $5.793 * *$ \\
\hline financial decisions on my own. & Japan & 83 & 38.1 & 134 & 61.5 & 1.618 & .487 & \\
\hline
\end{tabular}

Note. ${ }^{*}, * *$ indicate that the difference is significant at 5 -percent and 1-percent levels, respectively.

"Strongly disagree" and "Disagree" were coded as 1. "Agree" and "Strongly agree" were coded as 2.

Further analysis revealed that there was no statistically significant difference between those who were confident and those were less confident in making financial decisions in answering correctly financial literacy questions 
( ine questions, maximum points $=9$ ) in the US sample (mean of confident $=6.394$; mean of less confident $=$ $6.017 ; \mathrm{t}=1.535$ ) and in Japanese sample (mean of confident $=4.119$; mean of less confident $=4.148 ; \mathrm{t}=-.118$ ). See Table 3B. The US students in this study, regardless of their confidence level, scored significantly higher on the financial literacy test compared to Japanese students.

Table 3B. Results of independent samples t-test on financial literacy: scores of students confident in making financial decisions vs. scores of students less confident in making financial decisions

\begin{tabular}{llllll}
\hline Country & & $\mathrm{N}$ & Mean & SD & t-value \\
\hline \multirow{2}{*}{ US } & Confident & 289 & 6.394 & 1.745 & 1.535 \\
& Less confident & 59 & 6.017 & 1.603 & \\
\hline \multirow{2}{*}{ Japan } & Confident & 126 & 4.119 & 1.547 & -.118 \\
& Less confident & 76 & 4.148 & 1.430 & \\
\hline
\end{tabular}

Note. ${ }^{*}, * *$ indicate that the difference is significant at 5 -percent and 1-percent levels, respectively.

Scores are calculated by adding the number of correct response for the ten financial literacy questions. Thus, maximum score is 10 .

Table 3C reports results of independent samples t-test at different confidence levels. Japanese students who were confident in making financial decisions (mean in Japan $=4.119$ ) scored not only significantly lower than those of US students with confidence (mean in US $=6.395 ; \mathrm{t}=12.630 ; \mathrm{p}$-value significant at .01 level), but also lower than US students with less confidence (mean in US $=6.017$ ).

Table 3C. Results of independent samples t-test on financial literacy at different confidence levels in making financial decisions: scores of us students vs. scores of japanese students in making financial decisions

\begin{tabular}{llllllll}
\hline & US & \multicolumn{7}{c}{ Japan } \\
& $\mathrm{N}$ & Mean & SD & N & Mean & SD & t-value \\
\hline Confident & 289 & 6.395 & 1.745 & 126 & 4.119 & 1.547 & $12.630^{* *}$ \\
Less confident & 59 & 6.017 & 1.603 & 76 & 4.145 & 1.430 & $7.156^{* *}$ \\
\hline
\end{tabular}

Note. $*, * *$ indicate that the difference is significant at 5 -percent and 1-percent levels, respectively.

Scores are calculated by adding the number of correct response for the ten financial literacy questions. Thus, maximum score is 10 .

\section{Conclusion}

Researchers, educators, and policy makers would generally agree that lack of financial knowledge and skills have contributed to the latest economic and financial crisis (Klapper et al., 2012). There is a growing body of literature documenting the positive role financial education can play in improving knowledge, retirement planning, spending, and savings behavior (Bernheim, Garrett, \& Maki, 2001; Bernheim \& Garrett, 2003; Hilgert, Hogarth, \& Beverly, 2003; Clark, d'Ambrosio, McDermed, \& Sawant, 2004; Lyons et al, 2006), budgeting (Shelton \& Hill, 1995), and use of credit card (Armstrong \& Craven, 1993; Robb \& Sharpe, 2009). The primary purpose of our investigation was to compare and contrast the level of financial literacy as well as confidence in their own financial decisions between the US and Japan. We examined the level of personal financial literacy of college students.

This study provides a snapshot of financial education status of selected collegiate students in the US and Japan at a moment in time. The US collegiate students selected for this study demonstrated a better understanding of financial literacy measured by Lusardi and Mitchell (2006) and Jump\$tart instruments in comparison with the Japanese counterparts. Our findings were consistent with past research (Sekita, 2011) and the report published by OECD (2006).

Nearly half of Japanese students in this study did not feel that they were ready to make their own financial decisions. Their lack of confidence in making financial decision was regrettably reflected on their poor performance in the financial literacy test. What was even more alarming to us was that the Japanese students who were confident enough to make their financial decisions (mean $=4.707, \mathrm{SD}=1.800$ ) demonstrated their poor understanding of financial knowledge, even lower than the US students with less confidence $($ mean $=6.774$, $\mathrm{SD}=1.673)$, with $\mathrm{p}$-value significant at .01 level. Their confidence with no clear reasons may lead them to become victims of financial traps in the deregulated financial markets where access to credit or money is just a 
few clicks away. While it is generally acknowledged that education holds the key to increasing financial independence and confidence in making financial decisions in Japan, the record to date, including results in this study has not been encouraging when compared to that in the US.

The ultimate goal of financial education is to favorably affect consumer behavior, such as to promote saving and spending habits, wise use of credit, and avoidance of fraudulent or disadvantageous financial products. The next logical and ambitious step is to measure the impact of financial literacy on subsequent financial behavior, such as to promote improved saving and spending habits, wise use of credit, and avoidance of fraudulent or disadvantageous financial products in multiple cultural settings.

\section{Acknowledgments}

This work was supported by JSPS KAKENHI Grant Number 24730281.

\section{References}

$\begin{array}{lllll}\text { AFP } & \text { (Agence } & \text { France-Presse). } & \text { (2009). } & \text { Retrieved }\end{array}$ http://forums.vr-zone.com/newsroom/407915-news-aso-makes-another-gaffe.html

Ali, A., Rahman, M. S. A., \& Bakar, A. (2013). Financial literacy and satisfaction in Malaysia: A pilot study. International Journal of Trade, Economics and Finance, 4(5), 319-324. http://dx.doi.org/10.7763/IJTEF.2013.V4.309

Armstrong, C. J., \& Craven, M. J. (1993). Credit card use and payment practices among a sample of college students (pp. 48-159). Proceedings of 6th Annual Conference of the Association for Financial Counseling and Planning Education.

Balatti, J. (2007, November). Financial literacy and social networks-what's the connection? Presentation at the Adult Learning Australia National Conference, Cairns.

Bernheim, D., \& Garrett, D. (2003). The effects of financial education in the workplace: Evidence from a survey of households. Journal of Public Economics, 87(7-8), 1487-1519. http://dx.doi.org/10.1016/S0047-2727(01)00184-0

Bernheim, D., Garrett, D., \& Maki, D. (2001). Education and saving: The long-term effects of high school financial curriculum mandates. Journal of Public Economics, 80(3), 435-465. http://dx.doi.org/10.1016/S0047-2727(00)00120-1

Bucher-Koenen, T., \& Lusardi, A. (2011). Financial literacy and retirement planning in Germany. Journal of Pension Economics and Finance, 10(4), 565-584. http://dx.doi.org/10.1017/S1474747211000485

Clark, R., d'Amabrosio, M. B., McDermed, A. A., \& Sawant, K. (2004). Sex differences, financial education, and retirement goals. In O. S. Michell \& S. P. Utkus (Eds.), Pension design and structure (pp. 185-206). New York: Oxford University Press. http://dx.doi.org/10.1093/0199273391.003.0010

DeDonno, M. A., \& Fagan, J. F. (2013). The influence of family attributes on college students' academic self-concept. North American Journal of Psychology, 15(1), 49-62.

Dowling, N. A., Corney, T., \& Hoiles, L. (2009). Financial management practices and money attitudes as determinates of financial problems and dissatisfaction in young male Australian workers. Journal of Financial Counseling and Planning, 20(2), 5-12.

Fornero, E., \& Monticone, C. (2011). Financial literacy and pension plan participation in Italy. Journal of Pension Economics and Finance, 10(4), 547-564. http://dx.doi.org/10.1017/S1474747211000473

Hilgert, M., Hogarth, J. M., \& Beverly, S. G. (2003). Household financial management: The connection between knowledge and behavior. Federal Reserve Bulletin, July, 309-322.

Hussain, J., Matlay, H., \& Scott, J. M. (2008). Financial education in small ethnic minority businesses in the UK. Education and Training, 50(8/9), 737-747. http://dx.doi.org/10.1108/00400910810917109

Ji, H. J., Hanna, S. D., Lawrence, F. C., \& Miller, R. K. (2010). Two decades of the Journal of Financial Counseling and Planning. Journal of Financial Counseling and Planning, 21(1), 3-13.

Klapper, L., \& Panos, G. A. (2011). Financial literacy and retirement planning: the Russian case. Journal of Pension Economics and Finance, 10(4), 599-618. http://dx.doi.org/10.1017/S1474747211000503

Klapper, L., Lusardi, A., \& Panos, G. A. (2012). Financial literacy and the financial crisis.

Kusumoto, M. (2006). The problem with the financial education of Japan: Around the comparison of financial 
basic knowledge of Japan and the United States high school students (Nihon no Kinyu Kyoiku to sono Kadai) (pp. 143-156). Gendai Shakai Kenkyu Hokoku, Aichi Shukutoku University.

Lown, J. M., \& Ju, I. S. (2000). Adapting western financial education and counseling models for use in South Korea. Journal of Financial Counseling and Planning, 11(1), 61-69.

Lusardi, A., \& Mitchell, O. S. (2006). Financial literacy and planning: Implications for retirement well being. Working Paper, Pension Research Council, Wharton School, University of Pennsylvania.

Lusardi, A., \& Mitchell, O. S. (2007). Baby boomer retirement security: The roles of planning, financial literacy, and housing wealth. Journal of Monetary Economics, 54, 205-224. http://dx.doi.org/10.1016/j.jmoneco.2006.12.001

Lusardi, A., \& Mitchell, O. S. (2011). Financial literacy around the world: An overview. Journal of Pension Economics and Finance, 10(4), 497-508. http://dx.doi.org/10.1017/S1474747211000448

Lyons, A. C., Chang, Y., \& Scherpf, E. M. (2006). Translating financial education into behavior change for low-income populations. Journal of Financial Counseling and Planning, 17(2), 27-45.

Mandell, L. (2008). The Financial literacy of young American adults. The Jump\$tart Coalition for Personal Financial Literacy. Retrieved from http://www.jumpstart.org/assets/files/2008SurveyBook.pdf

Marcolin, S., \& Abraham, A. (2006). Financial literacy research: Current literature and future opportunities. 3rd International Conference of Contemporary Business. Retrieved from http://ro.uow.edu.au/cgi/viewcontent.cgi?article=1233\&context=commpapers

Marjoribanks, K. (2005). Correlations among family environment, academic achievement, and academic attainment in a large sample of young Australian adults. Psychological Reports, 97, 639-644.

Melhuish, E., Quinn, L., Sylva, K., Sammons, P., Siraj-Blatchford, I., \& Taggart, B. (2013). Preschool affects longer term literacy and numeracy: Results from a general population longitudinal study in Northern Ireland. School Effectiveness and School Improvement, 24(2), 234-250. http://dx.doi.org/10.1080/09243453.2012.749796

OECD. (2006). Policy Brief. Retrieved from http://www.oecd.org/dataoecd/8/32/37087833.pdf

Robb, C. A., \& Sharpe, D. L. (2009). Effect of personal financial knowledge on college students' credit card behavior. Journal of Financial Counseling and Planning, 20(1), 25-43.

Robb, C. A., Babiarz, P., \& Woodyard, A. (2012). The demand for financial professionals advise: The role of financial knowledge, satisfaction, and confidence. Financial Services Review, 21(4), 291-305.

Schwab, C. (2008). President's Advisory Council on Financial Literacy. Retrieved from http://www.jumpstart.org/assets/files/PACFL_ANNUAL_REPORT_1-16-09.pdf

Sekita, S. (2011). Financial literacy and retirement planning in Japan. Journal of Pension Economics and Finance, 10(4), 637-656. http://dx.doi.org/10.1017/S1474747211000527

Shahrabani, S. (2012). The effect of financial literacy and emotions on intent to control personal budget: A study among Israeli college students. International Journal of Economics and Finance, 4(9), 156-163. http://dx.doi.org/10.5539/ijef.v4n9p156

Shelton, G. G., \& Hill, O. L. (1995). First-time homebuyers programs as an impetus for change in budget behavior. Journal of Financial Counseling and Planning, 6, 83-91.

$\begin{array}{lllll}\text { U.S. Department } & \text { of } & \text { Treasury. } & \text { (2012). }\end{array}$ http://www.treasury.gov/resource-center/financial-education/Pages/CFAP.aspx

United States Government Accountability Office. (2011). Financial literacy: A federal certification process for providers would pose challenges. Retrieved from http://www.gao.gov/products/GAO-11-614

Van Rooij, M., Lusardi, A., \& Alessie, R. (2007). Financial literacy and stock market participation. Michigan Retirement Research Center Research Paper No. 2007-162. Retrieved from http://ssrn.com/abstract=1014994

Willis, L. E. (2011). The financial education fallacy. American Economic Review, 101(3): 429-434. http://dx.doi.org/10.1257/aer.101.3.429

Worthington, A. C. (2006). Predicting financial literacy in Australia. Financial Services Review, 15, 59-79. 


\section{Note}

Note 1. See http://www.iser.osaka-u.ac.jp/

Appendix A. Demographic Profile of Respondents

\begin{tabular}{|c|c|c|c|c|}
\hline & \multicolumn{2}{|c|}{ United States } & \multicolumn{2}{|c|}{ Japan } \\
\hline & Frequency & Percent & Frequency & Percent \\
\hline \multicolumn{5}{|l|}{ Age } \\
\hline$<20$ years & 65 & 18.3 & 114 & 52.8 \\
\hline $20-22$ years & 118 & 33.1 & 96 & 44.4 \\
\hline$>22$ years & 173 & 48.6 & 6 & 2.8 \\
\hline \multicolumn{5}{|l|}{ Gender } \\
\hline Male & 169 & 46.9 & 22 & 10.1 \\
\hline Female & 191 & 53.1 & 196 & 89.9 \\
\hline \multicolumn{5}{|l|}{ Education level (Father) } \\
\hline No college degree & 215 & 61.6 & 114 & 53.0 \\
\hline College degree or equivalent & 94 & 26.9 & 96 & 44.7 \\
\hline Graduate degree or equivalent & 40 & 11.5 & 5 & 2.3 \\
\hline \multicolumn{5}{|l|}{ Education level (Mother) } \\
\hline No college degree & 246 & 70.9 & 174 & 80.9 \\
\hline College degree or equivalent & 76 & 21.9 & 39 & 18.1 \\
\hline Graduate degree or equivalent & 25 & 7.2 & 2 & .9 \\
\hline
\end{tabular}

\section{Appendix B. Financial Literacy Survey}

\begin{tabular}{|c|c|}
\hline I am well-prepared to make financial decisions on my own. & $\begin{array}{l}\text { Measured by a four-point Likert scale, ranging from } \\
\text { "strongly disagree" (1) to "strongly agree: (4) }\end{array}$ \\
\hline \multicolumn{2}{|l|}{ Jump\$start questions } \\
\hline $\begin{array}{l}\text { Rebecca has saved } \$ 12,000 \text { for her college expenses by working } \\
\text { part-time. Her plan is to start college next year and she needs all of the } \\
\text { money she saved. Which of the following is the safest place for her } \\
\text { college money? }\end{array}$ & $\begin{array}{l}\text { 1. Locked in her closet at home. } \\
\text { 2. Stocks. } \\
\text { 3. Corporate bonds. } \\
\text { 4. A bank savings account. }\end{array}$ \\
\hline $\begin{array}{l}\text { Which of the following types of investment would best protect the } \\
\text { purchasing power of a family's savings in the event of a sudden increase } \\
\text { in inflation? }\end{array}$ & $\begin{array}{l}\text { 1. A } 10 \text {-year bond issued by a corporation } \\
\text { 2. A certificate of deposit at a bank } \\
\text { 3. A twenty-five year corporate bond } \\
\text { 4. A house financed with a fixed-rate mortgage }\end{array}$ \\
\hline $\begin{array}{l}\text { Many people put aside money to take care of unexpected expenses. If } \\
\text { Juan and Elva have money put aside for emergencies, in which of the } \\
\text { following forms would it be of LEAST benefit to them if they needed it } \\
\text { right away? }\end{array}$ & $\begin{array}{l}\text { 1. Invested in a down payment on the house } \\
\text { 2. Stocks } \\
\text { 3. Savings account } \\
\text { 4. Checking account }\end{array}$ \\
\hline $\begin{array}{l}\text { David just found a job with a take-home pay of } \$ 2000 \text { per month. He } \\
\text { must pay } \$ 900 \text { for rent and } \$ 150 \text { for groceries each month. He also } \\
\text { spends } \$ 250 \text { per month on transportation. If he budgets } \$ 100 \text { each month } \\
\text { for clothing, } \$ 200 \text { for restaurants and } \$ 250 \text { for everything else, how long } \\
\text { will it take him to accumulate savings of } \$ 600 \text { ? }\end{array}$ & $\begin{array}{l}\text { One months } \\
\text { Two months } \\
\text { Three month } \\
\text { Four months }\end{array}$ \\
\hline $\begin{array}{l}\text { Rob and Mary are the same age. At age } 25 \text {, Mary began saving } \$ 2000 \text { a } \\
\text { year while Rob saved nothing. At age } 50 \text {, Rob realized that he needed } \\
\text { money for retirement and started saving } \$ 4000 \text { per year while Mary kept } \\
\text { saving her } \$ 2000 \text {. Now they are both } 75 \text { years old. Who has the most } \\
\text { money in his or her retirement account? }\end{array}$ & $\begin{array}{l}\text { 1. They would each have the same amount because they } \\
\text { put away exactly the same } \\
\text { 2. Rob, because he saved more each year } \\
\text { 3. Mary, because she has put away each year } \\
\text { 4. Mary, because her money has grown for a longer time at } \\
\text { compound interest }\end{array}$ \\
\hline $\begin{array}{l}\text { Sara and Joshua had a baby. They received money as baby gifts and want } \\
\text { to put it away for the baby's education. Which tends to have the highest } \\
\text { growth over periods of time as long as } 18 \text { years? }\end{array}$ & $\begin{array}{l}\text { 1. Stocks } \\
\text { 2. A government savings bond } \\
\text { 3. A savings account } \\
\text { 4. Checking account }\end{array}$ \\
\hline
\end{tabular}




\begin{tabular}{|c|c|}
\hline Suppose you had $\$ 100$ in a savings account and the interest rate was $2 \%$ & 1. More than $\$ 102$ \\
\hline per year. After five years, how much do you think you would have in the & 2. Exactly $\$ 102$ \\
\hline account if you left the money to grow? & 3. Less than $\$ 102$ \\
\hline Imagine that the interest rate on your savings account was $1 \%$ per year & 1. more than \\
\hline and inflation was $2 \%$ per year. After one year, you would be able to buy & 2. exactly the same as \\
\hline $\begin{array}{c}\text { today with the money in this account. } \\
\end{array}$ & 3. less than \\
\hline $\begin{array}{l}\text { Do you think that the following statement is true or false? "Buying a } \\
\text { single company stock usually provides a safer return than a stock mutual } \\
\text { fund." }\end{array}$ & 1. True 2. False \\
\hline What is your gender? & 1. Male 2. Female \\
\hline What is your age? & [ ] years old \\
\hline The highest level of education your FATHER completed & 1. Middle school \\
\hline & 2. High school or equivalent \\
\hline & 3. Some college \\
\hline & 4. Associate degree \\
\hline & 5. BS/BA or equivalent \\
\hline & 6. Advanced degree \\
\hline & 7. I don't know/I refuse to answer \\
\hline The highest level of education your MOTHER completed & 1. Middle school \\
\hline & 2. High school or equivalent \\
\hline & 3. Some college \\
\hline & 4. Associate degree \\
\hline & 5. BS/BA or equivalent \\
\hline & 6. Advanced degree \\
\hline & 7. I don't know/I refuse to answer \\
\hline
\end{tabular}

\section{Copyrights}

Copyright for this article is retained by the author(s), with first publication rights granted to the journal.

This is an open-access article distributed under the terms and conditions of the Creative Commons Attribution license (http://creativecommons.org/licenses/by/3.0/). 